\begin{tabular}{|ll|}
\hline Received & $: 27$ March 2019 \\
Revised & $: 29$ March 2019 \\
Accepted & $:$ 12 September 2019 \\
Published & $: 27$ Desember 2019 \\
\hline
\end{tabular}

\title{
Utilization of Online Media as A Learning Media Bahasa Indonesia
}

\author{
Rawinda Fitrotul Mualafina ${ }^{1, a)}$ \\ 1 \\ Universitas PGRI Semarang \\ E-mail: ${ }^{\text {a) }}$ fina.rara@gmail.com
}

\begin{abstract}
This paper is a thought about the use of online media as a means of learning Indonesian. The method used is a qualitative method with data collection techniques with documentation and listening techniques. The analysis shows that online media, whether in the form of channels, online applications, and social media, can be effective learning media in addition to printed literature. Online media, as a learning tool, can also be an easier medium for language recognition and marketing in the community so that language knowledge is not only shared by language activists, but also the wider Indonesian community as its native speakers.
\end{abstract}

Keywords: teaching, learning, language, online media, social media, Indonesian

\begin{abstract}
Abstrak
Tulisan ini merupakan buah pikiran mengenai pemanfaatan media daring sebagai sarana pembelajaran bahasa Indonesia. Metode yang digunakan metode kualitatif dengan teknik pengambilan data dengan teknik dokumentasi dan teknik simak. Hasil analisis menunjukkan bahwa media daring, baik yang berupa kanal, aplikasi daring, dan media sosial, dapat menjadi media belajar yang efektif di samping literatur cetak. Media daring, sebagai sarana belajar, dapat pula menjadi media pengenalan dan pemasaran bahasa pada masyarakat yang lebih mudah sehingga pengetahuan bahasa tidak hanya dimiliki oleh kalangan pegiat bahasa, tetapi juga masyarakat Indonesia secara luas sebagai penutur aslinya.
\end{abstract}

Kata kunci: pengajaran, pembelajaran, bahasa, media daring, media sosial, bahasa Indonesia 


\section{PENDAHULUAN}

Sejak awal kemunculannya, media daring seakan dapat mengatasi kerisauan masyarakat mengenai banyak hal. Jarak jauh, waktu yang lama, termasuk kesibukan pekerjaan, seakan tidak lagi menjadi kendala yang berarti untuk tetap berkabar, berkirim barang, sampai dengan berbelanja. Rahmawati dan Anindhita (2016:730). Media pembelajaran adalah alat saluran komunikasi, media berasal dari bahasa Latin yang memiliki pengertian yaitu perantara antara sumber pesan dengan penerima pesan, hal ini dinyatakan oleh (Heinich, 2005:141). Lebih lanjut, (Gagne dalam Sadiman, 1996:6) menyatakan bahwa media adalah berbagai jenis komponen dalam lingkungan siswa yang dapat memberikan rangsangan untuk belajar. (Miarso, 2004: 457) dalam penelitiannya menyebutkan bahwa segala keterbatasan yang dimiliki media konvensional dapat teratasi dengan keberadaan media daring. Mulai munculnya perpesanan instan dengan orang tak dikenal seperti mLRC, lalu yahoo messenger, sampai dengan adanya surat elektronik dan media sosial yang sekarang marak digunakan, menjadikan semuanya menjadi semakin mudah bahkan sangat mudah. Termasuk youtube dan goodreads yang memudahkan masyarakat mengakses segala hal. Teknologi telah menggeser paradigma berfikir manusia dan menjadikan pilihan hidup yang menjadi prioritas kehidupan. Dampak globalisasi saat ini, tak terbantahkan lagi menjadikan teknologi gaya hidup milenial (Manggong, 2019). Teknologi adalah ilmu tentang cara menerapkan sains untuk memanfaatkan alam bagi kesejahteraan dan kenyamanan manusia (Ahmad Y. Al-Hasan dan Ronald R. Hill, 1993 : 17).

Seorang ibu tidak perlu lagi membeli buku resep untuk mencontoh cara memasak daging, misalnya, atau seorang penyuka novel tidak perlu lagi pergi ke toko buku karena gawai yang dimilikinya sudah memberikan kemudahan untuk membeli buku secara online berupa e-book untuk bisa dinikmati secara langsung. Semua kemudahan itu merupakan sejumlah bentuk pemanfaatan media daring yang dapat dikatakan menjadi hal yang sangat dekat dan selalu diinginkan untuk dekat oleh masyarakat, Pemilihan model pembelajaran akan menjadikan proses pembelajaaran lebih variatif, inovatif sehingga dapat meningkatkan aktivitas dan kreativitas siswa, sehingga prestasi belajar siswa dapat meningkat (Trianto, 2010:8-9). tidak hanya Indonesia tetapi juga dunia. Jika dulu orang butuh tas besar untuk mengangkut kamera, buku, laptop, bahkan mungkin walkman atau ipod, saat ini seserang hanya butuh kantong celana atau baju sebagai tempat ponsel yang telah memuat kesemua hal tadi dalam satu alat. Menurut Martin (1999), Teknologi informasi tidak hanya terbatas pada teknologi komputer (perangkat keras dan perangkat lunak) yang akan digunakan untuk memproses dan menyimpan informasi, melainkan juga mencakup teknologi komunikasi untuk mengirim/menyebarkan informasi.

Salah satu kemudahan yang kemudian secara khusus dapat disoroti adalah bahwa media daring tersebut dapat menjadi media belajar. Tidak hanya berupa kanal belajar yang secara umum dijadikan media sekolah informal, seperti Ruang Guru yang baru-baru ini marak diperbincangkan karena keunggulannya. Media daring tersebut pun akhirnya secara khusus dapat menjadi media belajar dalam bidang bahasa bagi masyarakat. Aplikasi kamus bahasa Indonesia yang diterbitkan oleh Pusat Bahasa menjadi salah satu yang sangat memudahkan masyarakat dalam pencarian definisi kata atau sekadar mengecek bentuk kata yang baku dalam bahasa Indonesia. Media sosial seperti twitter dan instagram, misalnya, termasuk pula kanal Youtube dan media 
percakapan daring, seperti whatsapp, juga dapat menjadi media belajar bahasa yang kekinian di samping aplikasi tadi. Hal ini tidak hanya dilihat dari kedekatannya dengan pengguna, tetapi juga dari fitur yang ditawarkan pada aplikasi media daring tersebut.

Sebagai contoh, seorang pegiat bahasa, Ivan Lanin, telah memulai pembelajaran bahasa melalui media daring sejak tahun-tahun awal kemunculan media sosial twitter. Pada hampir setiap unggahan kiriman di media sosialnya tersebut, beliau memberikan sekelumit info tentang bahasa, baik berupa ejaan maupun kata baku dalam bahasa Indonesia sesuai dengan kaidah tata bahasa yang berlaku.

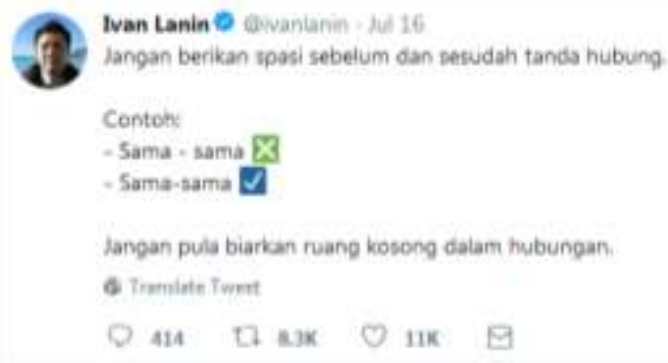

Gambar 1. Contoh kiriman mengenai ejaan berupa penggunaan tanda baca

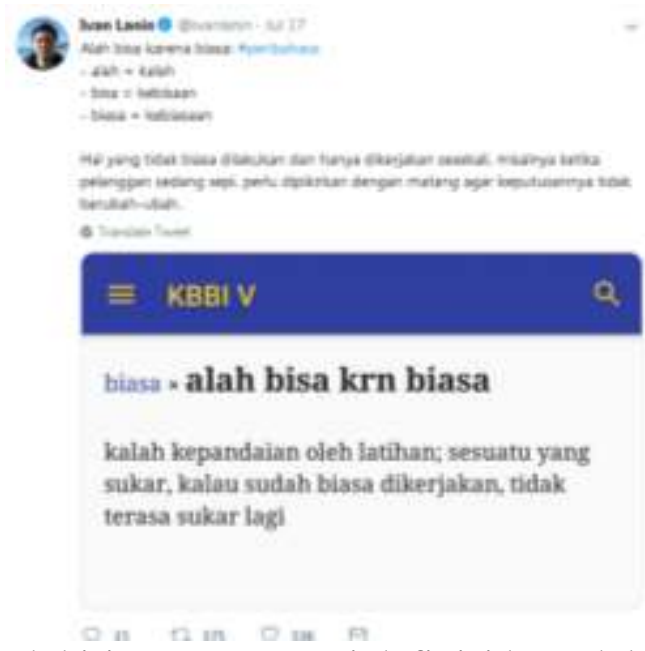

Gambar 2. Contoh kiriman mengenai definisi kata dalam $K B B I$ daring

Hal yang sama pun beliau lakukan melalui media sosial instagramnya. Dengan sejumlah usaha dan cara tersebut, kiranya pembelajaran bahasa tidak hanya untuk dipelajari tetapi juga diterima sebagai sesuatu yang menyenangkan. Apalagi di tengah maraknya bahasa asing yang memiliki prestise dan kesan menarik lainnya, seperti bahasa Inggris, Jepang, bahkan Korea yang sedang marak-maraknya, tentunya cara ini dapat menjadi cara mendekatkan bahasa Indonesia lebih intim dengan penutur aslinya. Buku tidak lagi satu-satunya sumber belajar bahasa bagi masyarakat. Mereka juga dapat melakukannya dengan mengakses pembelajaran bahasa itu melalui media daring yang dimiliki dan yang pasti lebih diminatinya. Minimal dengan cara ini, yang menikmati bahasa Indonesia tidak hanya pembelajar bahasa Indonesia di bangku kuliah atau sekolah, Bahasa Indonesia merupakan bahasa persatuan yang menjadi identitas bangsa Indonesia. Salah satu cara untuk menjaga kelestarian dan kemurnian bahasa Indonesia adalah dengan menuliskan kaidahkaidah ejaan dan tulisan bahasa Indonesia dalam sebuah buku yang di-sebut dengan Pedoman Umum Ejaan Bahasa Indonesia yang 
Disempurnakan (PUEYD) (2016). PUEYD dapat digunakan sebagai pedoman dalam kegiatan berkomunikasi menggunakan bahasa Indonesia dengan benar dalam komunikasi yang sifatnya formal. Selain itu, juga ada buku-buku pedoman yang lain seperti Pedoman Umum Pembentukan Istilah (2006), Tata Bahasa Baku Bahasa Indonesia (2000), Kamus Besar Bahasa Indonesia (2002), Undang-Undang Republik Indonesia Nomor 24 Tahun 2009 tentang Bendera, Bahasa, dan Lambang Negara, serta Lagu Kebangsaan (2011), dan sebagainya. tetapi juga masyarakat secara umum dan terbiasa menggunakan bentuk-bentuk bahasa yang ternyata masih banyak mengandung kesalahan yang dianggap lazim.

\section{METODE PENELITIAN}

Dalam penelitian ini, peneliti memilih jenis penelitian kualitatif maka data yang diperoleh haruslah mendalam, jelas dan spesifik. Menurut Sukmadinata (2005) dasar penelitian kualitatif adalah konstruktivisme yang berasumsi bahwa kenyataan itu berdimensi jamak, interaktif dan suatu pertukaran pengalaman sosial yang diinterpretasikan oleh setiap individu. Peneliti kualitatif percaya bahwa kebenaran adalah dinamis dan dapat ditemukan hanya melalui penelaahan terhadap orang-orang melalui interaksinya dengan situasi sosial mereka (Danim, 2002). Penelitian kualitatif mengkaji perspektif partisipan dengan strategi-strategi yang bersifat interaktif dan fleksibel. Penelitian kualitatif ditujukan untuk memahami fenomena-fenomena sosial dari sudut pandang partisipan. Dengan demikian arti atau pengertian penelitian kualitatif tersebut adalah penelitian yang digunakan untuk meneliti pada kondisi objek alamiah dimana peneliti merupakan instrumen kunci (Sugiyono, 2005). Pada penelitian ini peneliti mendapatkan data dari studi pustaka yaitu teknik pengumpulan data yang dilakukan dengan mempelajari buku-buku referensi, laporan-laporan, majalahmajalah, jurnal-jurnal dan media lainnya yang berkaitan dengan obyek penelitian.

\section{HASIL DAN PEMBAHASAN}

\section{Bentuk pemanfaatan media daring}

Sebagaimana dipaparkan sebelumnya, media daring hadir dalam berbagai bentuk aplikasi yang dapat dinikmati dan dimanfaatkan oleh masyatakat secara luas. Di antara banyak aplikasi yang ada terrsebut, sebagian kecilnya telah dimanfaatkan oleh sejumlah pihak sebagai sarana belajar, khususnya belajar bahasa Indonesia.

\section{Aplikasi daring}

1) Kamus Besar Bahasa Indonesia

Selama ini, kamu bahasa Indonesia atau Kamus Besar Bahasa Indonesia (KBBI) selalu hadir dalam bentuk cetakan yang tidak hanya tebal, tetapi juga besar dan berat. Kondisi tersebut membuat sebagian besar orang malas membawa kamus 
sebagai buku bacaan di perjalanan atau sebagai salah satu barang bawaan dalam jarak tempuh yang jauh. Ketika kemudian media daring hadir sebagai bentuk kemudahan bagi masyarakat, Badan Bahasa, Kemendikbud Republik Indonesia, menerbitkan KBBI dalam bentuk yang ringkas dan sangat mudah untuk dibawa ke mana pun kita pergi. Kamus ini diterbitkan secara resmi oleh Badan Bahasa pada 27 Oktober 2016 dalam bentuk kamus edisi kelima setelah edisi keempat diterbitkan hanya dalam bentuk cetakan bersampul kuning emas pada tahun 2008. Melalui aplikasi KBBI ini, masyarakat tidak hanya dapat mengakses definisi tiap kosakata dalam bahasa Indonesia, tetapi juga secara tidak langsung dapat mengecek kebakuan suatu kosakata dalam bahasa Indonesia.
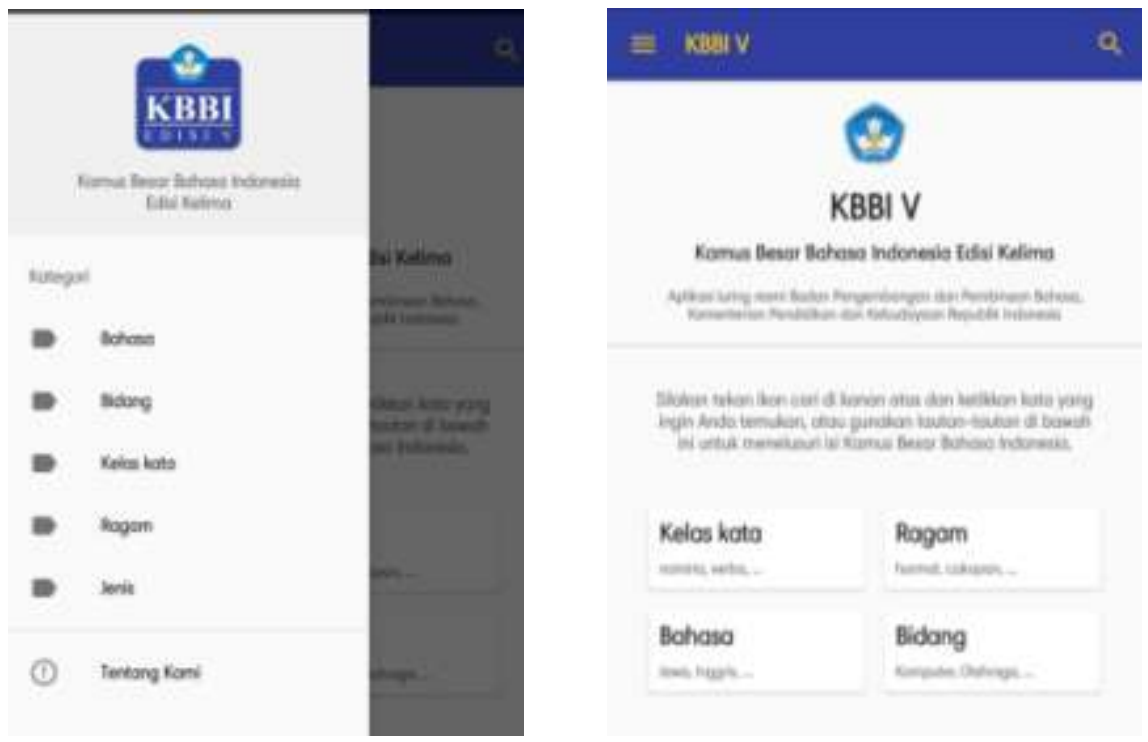

Gambar 3. Aplikasi KBBI daring

2) Ejaan Bahasa Indonesia

Selain kamus, masyarakat pun memperoleh kemudahan dalam mengakses kaidah ejaan. Setelah Ejaan yang Disempurnakan, diterbitkan kaidah ejaan baru dengan nama yang baru pula, yaitu Ejaan Bahasa Indonesia (EBI) pada April 2017. Sebagaimana kamus, EBI ini juga hadir dalam bentuk aplikasi daring yang juga memberikan kemudahan. Masyarakat tidak lagi harus membawa buku ejaan ke mana-mana, tetapi cukup dengan aplikasi yang mudah didapatkan secara gratis. Jika dibandingkan dengan kamus, buku ejaan memang relatif tipis dan tidak sebesar cetakan kamus. Namun, ketika kemudian buku tersebut hadir dalam bentuk aplikasi, tidak hanya kemudahan yang diperoleh tetapi juga secara tidak langsung ejaan bahasa Indonesia menjadi lebih dekat dengan masyarakat karena notabene ketika ejaan tersebut hadir dalam bentuk buku cetakaan, hanya sebagian orang yang berminat membeli, membuka, sampai mempelajarinya. Namun, ketika hadir dalam bentuk aplikasi, ejaan tersebut seakan menjadi aplikasi yang bisa dimiliki siapapun dan menjadi lebih dekat dengan masyarakat.

Sebagaimana versi cetakannya, aplikasi EBI ini berisi rincian kaidah ejaan secara detail. Seperti yang tampak pada gambar berikut ini, daftar isi EBI tertera dengan jelas. Pengguna dapat dengan mudah memilih kaidah sesuai dengan yang 
dikehendakinya, mulai penulisan abjad, penulisan huruf, sampai dengan tanda baca dan penulisan imbuhan.

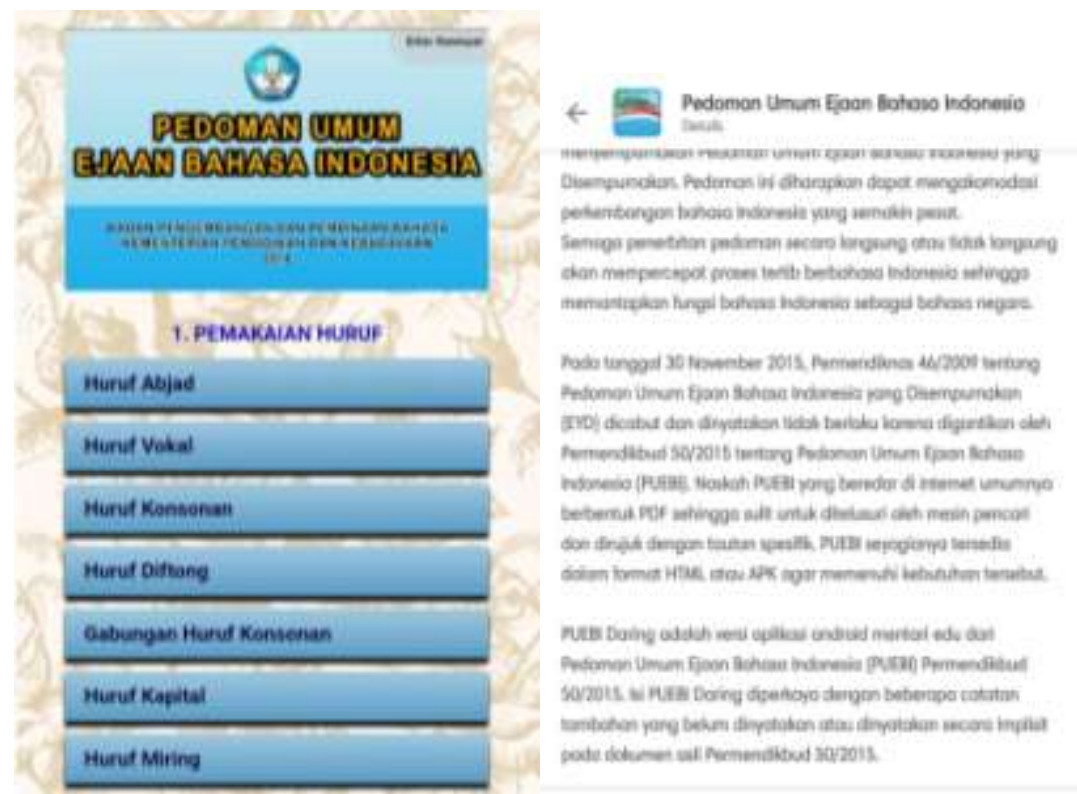

Gambar 4. Aplikasi EBI daring

\section{Media Sosial}

Media sosial sebagai bagian dari media daring menjadi hal yang hampir semua orang miliki. Sejak kegencaran media sosial berupa Friendster pada tahun-tahun awal 2000-an, lalu beralih ke Facebook, Facebook sendiri merupakan media sosial yang memiliki pengguna paling tinggi dan lebih dari 50\% penggunanya selalu mengunjungi aplikasi ini hampir setiap hari. Laporan tersebut juga menemukan bahwa kebanyakan masyarakat saat ini memiliki kurang lebih lima akun media sosial (Rohampton, 2017), sampai akhirnya mulai ditinggalkan dan digantikan dengan Twitter dan Instagram, masyarakat semakin terbiasa berkomunikasi dan berkegiatan dengan media sosial tersebut dalam kesehariannya. Sebagai bagian dari masyarakat itu kemudian media sosial menjadi salah satu sarana belajar bahasa yang menarik. Dua di antaranya adalah Twitter dan Instagram. Bentuk pemanfaatan pada kedua media sosial tersebut pun beragam, di antaranya berupa kiriman pembahasan kaidah bahasa secara ringkas dan menarik, serta berupa kuis dengan memanfaatkan fitur yang disediakan pada kedua media sosial tadi. Menurut Defleur dan Dennis (2005:158) mengemukakan komunikasi massa adalah : suatu proses dalam mana komunikator-komunikator menggunakan media untuk menyebarkan pesan-pesan secara luas, dan secara terus menerus menciptakan makna-makna yang diharapkan dapat mempengaruhi khalayak yang besar dan berbeda-beda dengan melalui berbagai cara.

Sebagaimana disebutkan sebelumnya, Ivan Lanin sebagai pegiat bahasa, menjadi pemilik akun twitter dan instagram yang pada sebagian besar kiriman daringnya berisi pembahasan kaidah-kaidah bahasa Indonesia. Kirimannya tersebut disampaikan dalam beberapa jenis pembahasan, yaitu pembahasan ejaan, leksem pada kamus, termasuk pula pembahasan kaidah kalimat bahasa Indonesia. 


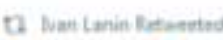

Nan Lanin 0 deivariarin : 27 Decc 201

Hanya pronomina persona "Anda" yang selaiu diawall hurvef lapitak. Kata gant

orang "kamu": "saya". dib. tidak diawali hurut kapital saat dpakai di tengah

balmat.

\section{Contoh:}

- Mi buke Anda.

- Ini buku kamy

- Ini buku saya.

o Trmaline Tiner

9 $10 \quad 17$ as

Gambar 5. Kiriman berupa penggunaan huruf kapital

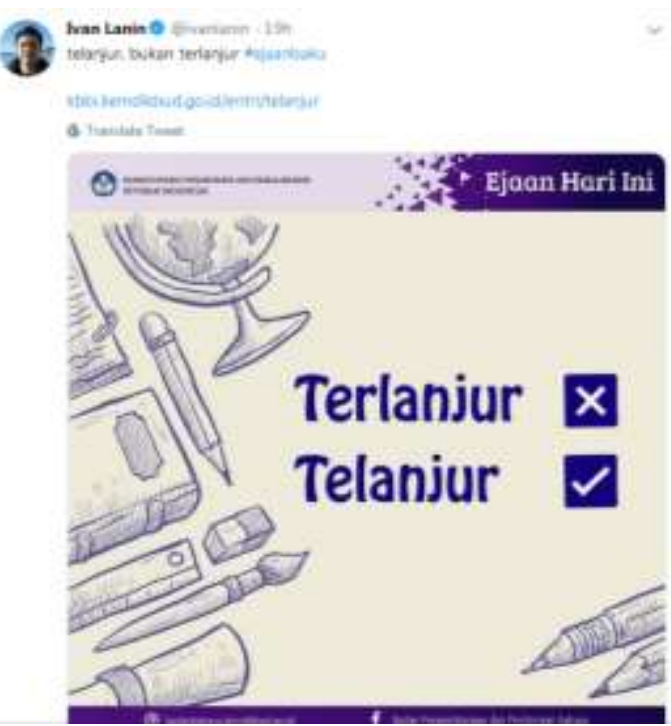

Gambar 6. Kiriman berupa leksem baku dalam kamus

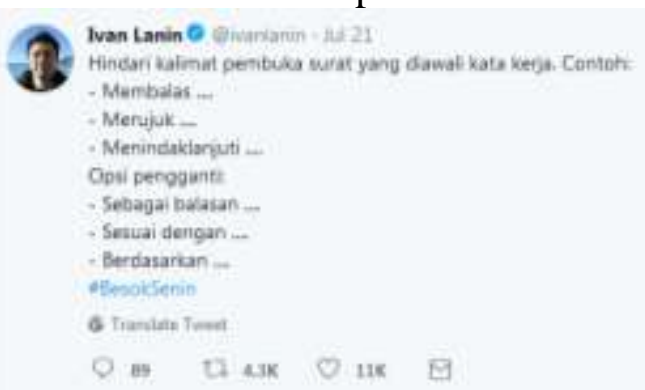

Gambar 8. Kiriman berupa penulisan kalimat yang tepat

Akun@spa_si juga menjadi akun lain yang mengisi hampir semua kirimannya melalui media sosial twitter berupa pembahasaan mengenai kaidah bahasa. Dua di antaranya tampak pada gambar berikut ini yang isinya berupa penulisan kalimat tanya yang benar sesuai dengan kaidah dan penulisan tanda baca yang tepat dalam bahasa Indonesia. 


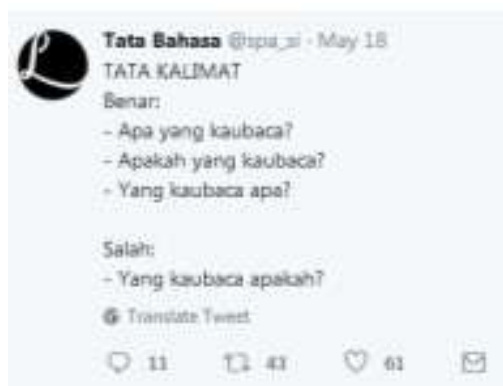

Gambar6. Kiriman@spa_si berupa penulisan kalimat tanya yang tepat

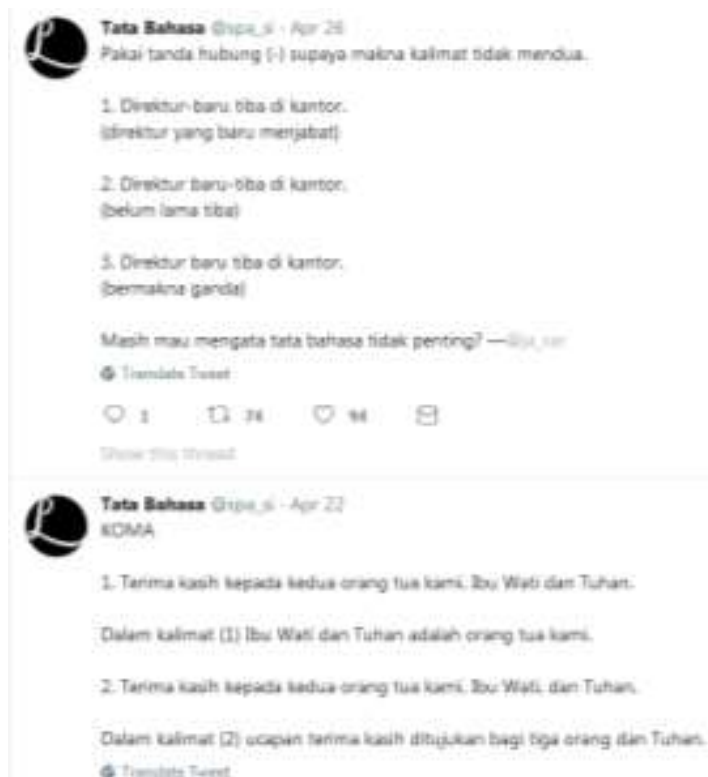

Gambar 7. Kiriman@spa_si berupa penggunaan tanda baca yang tepat

Pemanfaatan media sosial sebagai sarana belajar bahasa pun tampak melalui kanal Youtube. Media ini mengutamakan konten video sebagai sarana penyampai informasinya. Salah satu yang menjadi konten di dalamnya adalah video pembelajaran, tidak terkecuali pembelajaran bahasa. Sebagaimana tampak pada gambar berikut, khusus untuk kata kunci 'belajar bahasa Indonesia' saja dapat memunculkan banyak pilihan hasil pencarian.

Jika dilihat dari hasil yang muncul tersebut, tampak bahwa bahasa Indonesia tidak hanya difokuskan untuk dipelajari di sekolah sebagai mata pelajaran, tetapi juga sebagai sebuah pengetahuan umum kebahasaan yang dapat dipelajari oleh masyarakat secara umum, bahkan penutur asing sekalipun. Hal tersebut tampak pada pilihan hasil pencarian berupa 'belajar bahasa Indonesia untuk penutur asing'. Tentunya hal ini menjadi hal yang menarik bahwa selain melalui kelas-kelas BIPA di lembaga kebahasaan atau pun di perguruan tinggi, bahasa Indonesia bagi penutur asing pun dapat dipelajari melalui media sosial berupa kanal Youtube tersebut. 


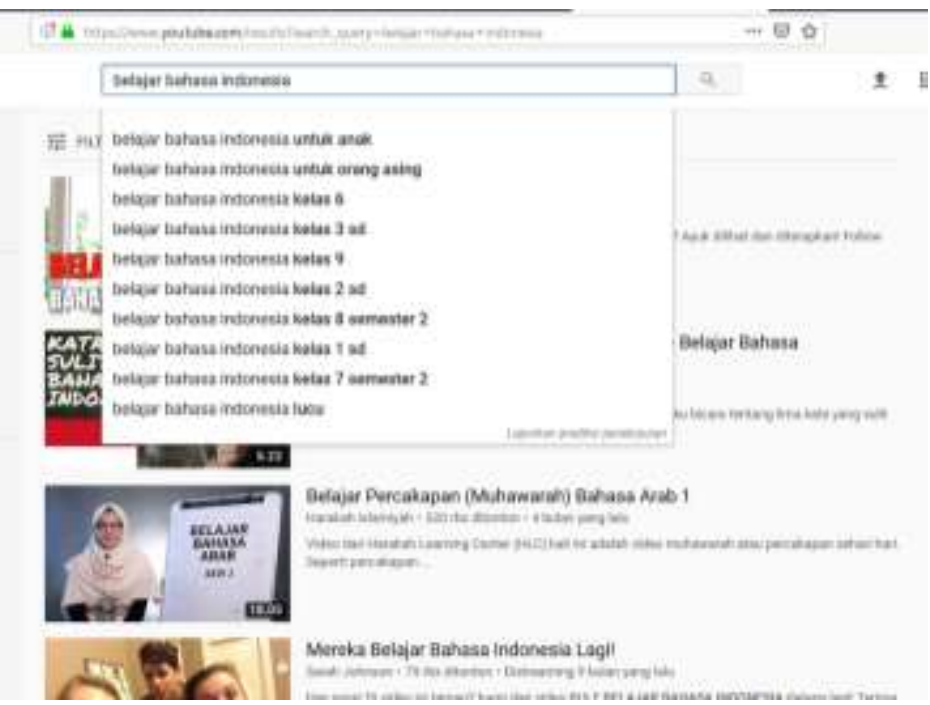

Gambar 8. Hasil pencarian kata kunci belajar bahasa Indonesia

Selain berupa kiriman, sebagaimana disampaikan tadi, pemanfaatan media sosial dalam hal pembelajaran bahasa juga dapat hadir berupa kuis-kuis sederhana. Salah satunya yang dapat diadakan melalui pemanfaatan fitur kuis pada media sosial instagram, sebagaimana tampak pada gambar berikut. Pemberian kuis ini, pada awalnya, diharapkan dapat menimimalkan kecenderungan bahwa belajar bahasa Indonesia, apalagi yang berkaitan dengan kaidah, merupakan sesuatu yang membosankan. Melalui kuis dengan tampilan dan bentuk yang menarik, diharapkan ilmu yang disisipkan di dalamnya dapat tersampaikan dengan menarik pula. Sebuah literatur yang diterbitkan oleh Unicef (2018:7) menyebutkan bahwa bermain menjadi satu sarana belajar yang sangat efektif untuk penyerapan pengetahuan. Berkaitan dengan hal tersebut, sebuah survei ilmiah yang dilakukan oleh Jabeen dan Thomas (2015) menunjukan bahwa sebagian responden yang diteliltinya mengharapkan lebih banyak materi belajar tambahan berupa kuis dalam sejumlah pembelajaran bahasa yang dilakukannya. 


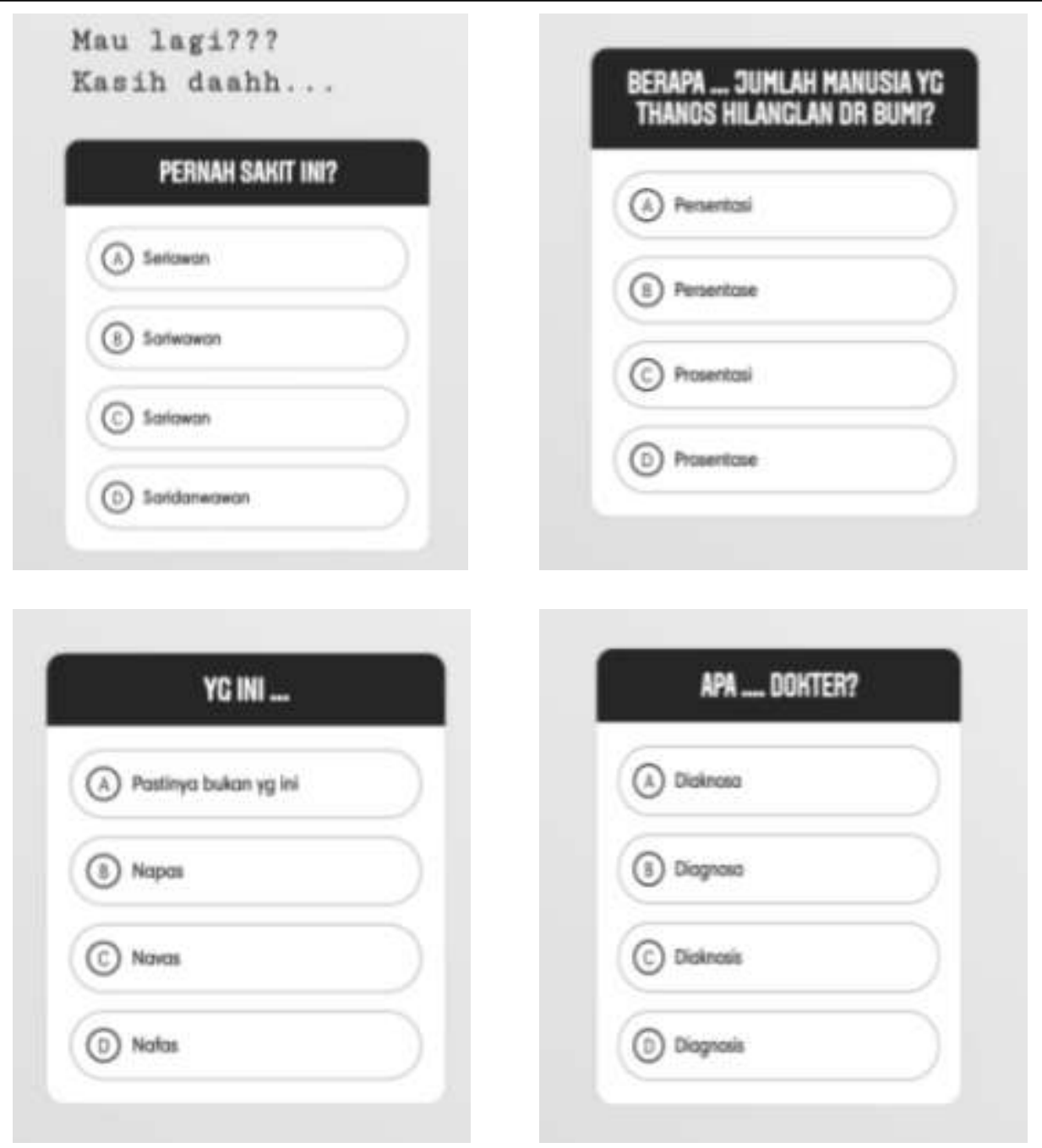

Gambar 9. Contoh kuis EBI melalui aplikasi instagram

Sejumlah tangkapan layar tersebut merupakan sejumlah contoh kuis yang dapat diberikan melalui media sosial instagram mengenai EBI. Kuis ini dapat diikuti oleh seluruh pengikut (followers) pada suatu akun dengan bebas. Pada pemberian kuis yang pernah dilakukan, ternyata banyak dari responden yang akhirnya menikmati kuis tersebut yang berasal dari luar sasaran. Dalam hal ini, sasaran sesungguhnya adalah mahasiswa bahasa, sebagai pengikut terbanyak pada akun tersebut. Dalam arti bahwa pembelajaran yang mengasyikkan ini tidak hanya kemudian ditujukan dan akhirnya dinikmati oleh mereka yang giat dalam bidang bahasa, seperti mahasiswa sastra dan bahasa. Namun, orang-orang dari luar bidang bahasa pun dapat turut menikmati dan mengikutinya dengan antusias. Keantusiasan ini tampak pada respon sejumlah pengikut yang meminta kuis serupa kembali diadakan. Dari banyak jawaban yang kemudian diberikan, sebagian besar soal terjawab dengan jawaban yang salah. Beberapa yang melakukan kesalahan itu kemudian merespon kuis dengan mengirimkan pesan pribadi (direct message) pada pemiliki akun dan mengakui bahwa banyak dari soal yang tidak dijawabnya dengan benar. 
Saya solah dua kali bu $\mathcal{C}_{2}$
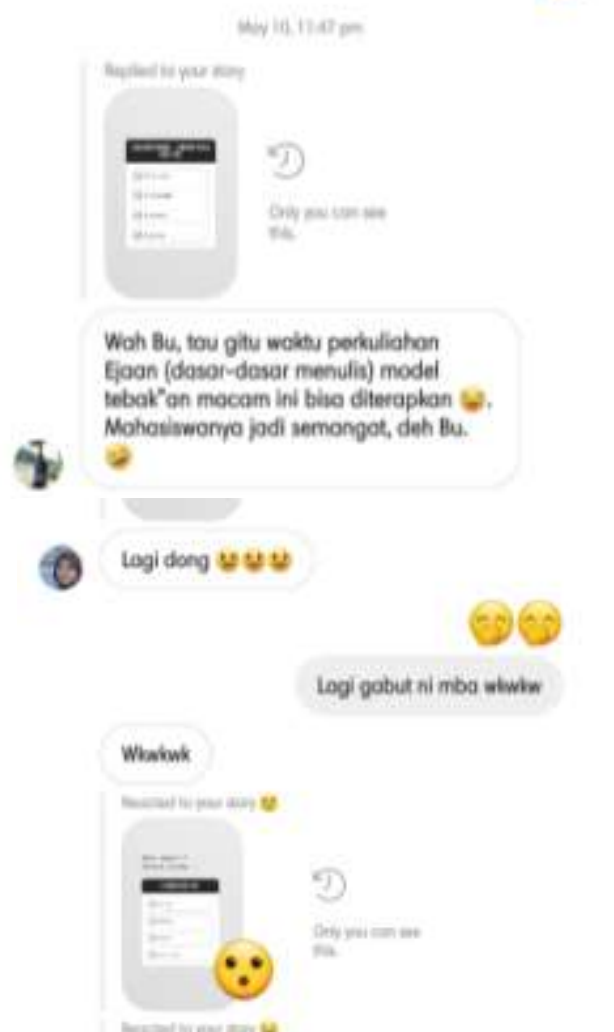

Buset $\sec 6 \mathrm{~s}$

Logi dong, gawot troks

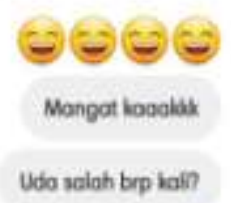

Bonyok whenkex.

Logil log

$\log$

Pate igo bu

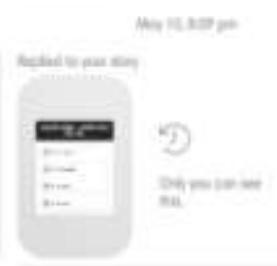

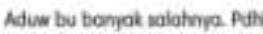
mohoises divir whak mungain dikorenokan overobais reviai taripal is

O oumbieives

Gambar 10. Respon dari responden terhadap kuis EBI melalui aplikasi Instagram

Berdasar pada sejumlah respon tersebut secara luas dapat diketahui bahwa melalui pengadaannya, kuis ini tidak hanya menjadi sarana belajar sambil bermain semata. Dalam hal ini, kuis tersebut secara lebih luas kemudian dapat secara tidak langsung mempromosikan bahasa Indonesia yang benar dalam kaidah bahasa Indonesia. Selain itu, secara luas, pengadaan kuis tersebut pun menumbuhkan kesadaran bahwa bentuk-bentuk bahasa yang bahkan sudah sangat banyak digunakan oleh masyarkat secara umum ternyata tidak sepenuhnya dan belum tentu merupakan bentuk bahasa yang benar. Kesadaran itu kemudian akan lebih baik jika kemudian mengarahkan masyarakat, yang dalam hal ini responden pada kuis tersebut, menjadi lebih semangat untuk mencari tahu mengenai bahasa pribuminya dan berusaha memperbaikinya, bahkan kemudian menggunakannya dalam keseharian.

\section{Penugasan melalui media percakapan Whatsapp}

Agak berbeda dengan pemanfaatan media daring sebelumnya yang fokus pada penggunaan media sosial, ternyata media daring lain, seperti aplikasi whatsapp atau yang lebih akrab disebut dengan WA pun dapat menjadi sarana pembelajaran bahasa. Dalam hal ini, whatsapp sebagai salah satu aplikasi perpesanan yang praktis tidak hanya dapat diamanfaatkan sebagai penyampai informasi kebahasaan, tetapi, lebih jauh lagi, bahwa aplikasi perpesanan tersebut dapat menjadi sarana praktik keterampilan bahasa. 
Pemanfaatan media WA ini berbasis sistem kelas daring yang dicanangkan oleh pihak kampus sebagai salah satu sistem pembelajaran selain pertemuan langsung di dalam kelas.

Proses pembelajaran bahasa melalui media daring ini diawali dengan pemberian materi di kelas sebagai bekal untuk mahasiswa secara teoretis. Materi yang diberikan mencakup materi kata, frasa, kalimat, sampai dengan ejaan. Adapun sebagai bekal praktisnya, dosen kemudian memberikan tugas khusus sebagai pengaplikasian materi yang telah diberikan di kelas. Pada bagian pengaplikasian inilah pemanfaatan media daring berupa WA tadi dilakukan. Dalam praktiknya, mahasiswa diminta menuliskan sebuah pesan dengan konteks yang ditentukan oleh dosen untuk dikirimkan kepada dosen pengampu mata kuliah tersebut melalui aplikasi WA. Pesan tersebut harus ditulis dengan bahasa dan kaidah ejaan yang sesuai dengan tata bahasa baku bahasa Indonesia dan ejaan bahasa Indonesia. Mahasiswa akan mendapatkan balasan revisi jika pesan yang dikirimkan masih mengandung kesalahan bahasa dan mendapatkan balasan oke dari dosen jika pesan yang dikirimkan sudah ditulis dengan bahasa dan kalimat yang baik dan benar sesuai kaidah. Cara pengajaran semacam ini telah dipraktikkan melalui Mata Kuliah Umum Bahasa Indonesia dan Mata Kuliah Dasar-dasar Menulis di Universitas PGRI Semarang.

Dari pratik kebahasan melalui WA ini terdapat mahasiswa yang dapat langsung memperoleh respon oke karena bentuk pesan yang dikirimkan sudah mengandung kaidah bahasa yang tepat. Ada pula yang beberapa kali salah dan mengulangi kesalahan yang sama ketika konteks pesan telah dinyatakan benar.

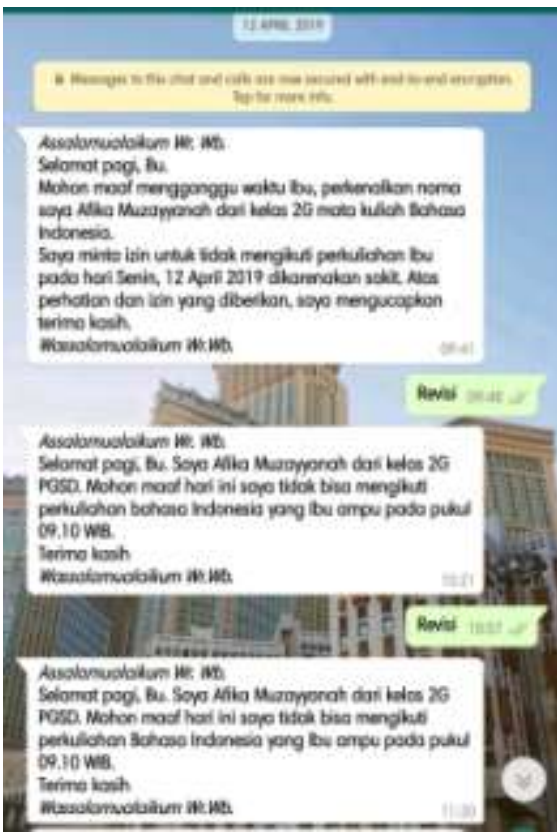



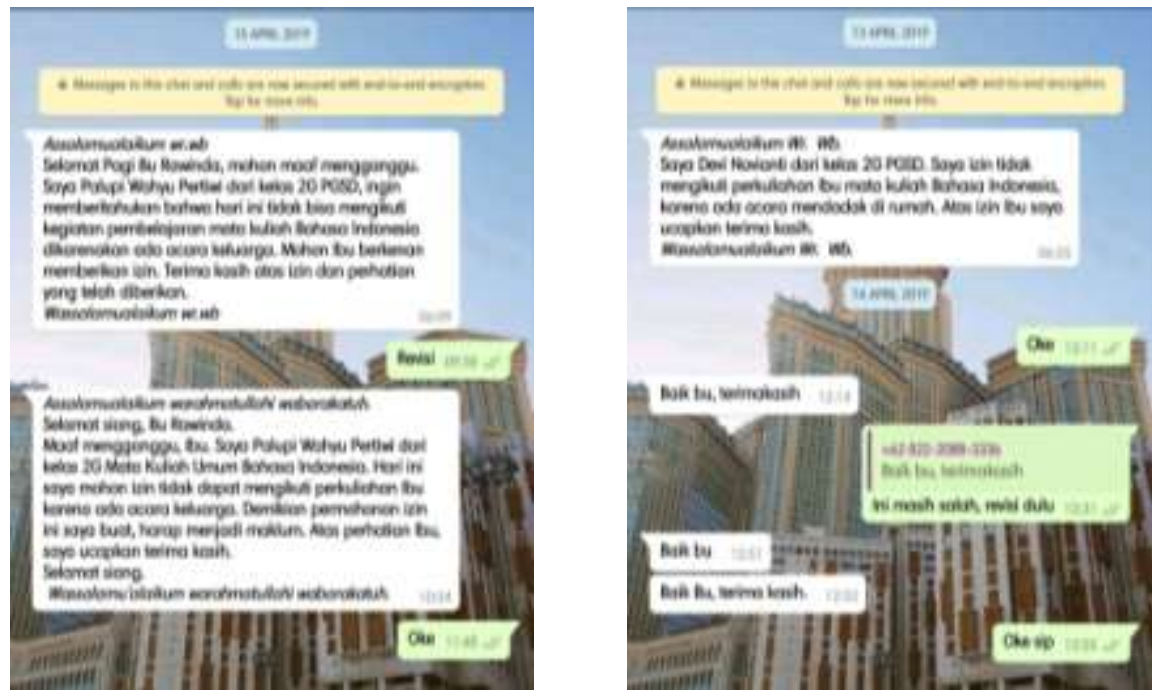

Gambar 11. Pemberian tugas praktik EBI melalui WA

Tujuan dari diberikannya tugas semacam ini melalui pemanfaatan media daring berupa WA ini adalah tidak hanya memanfaatkan media daring semata sebagai satu media perpesanan yang bahkan dapat dipastikan hampir semua mahasiswa miliki. Pemanfaatan media WA dalam pembelajaran kaidah bahasa ini juga sebagai satu langkah awal penegasan bahwa kaidah bahasa tidak hanya ilmu hapalan yang hanya sampai pada tahap ingatan. Kaidah bahasa justru lebih penting merupakan sesuatu yang wajib dipraktikkan. Aplikasi WA sebagai satu hal yang pasti dimiliki mahasiswa adalah hal yang dekat dengan kehidupan mereka. Dengan mempratikkan langsung pada hal yang dekat dengan mahasiswa, diharapkan mahasiswa tidak hanya semata-mata berkomunikasi, tetapi juga sembari mempraktikkan ilmu yang diperolehnya di kelas, yang dalam hal ini adalah materi dan ilmu bahasa. Dalam arti lain, mahasiswa dapat mempraktikkan materi kebahasaan itu dalam kesehariannya untuk kemudian menjadi kebiasaan.

Pada tahap selanjutnya, kebiasaan itu tidak hanya berhenti sebagai kebiasaan untuk menulis dengan benar, tetapi lebih jauh justru mengoreksi tulisan dan bahasa yang mengandung kesalahan untuk menjadi benar dan sesuai dengan kaidah. Sebagaimana Dunar (2015:10) menyebutkan bahwa keterampilan bahasa sama dengan keterampilan menyetir mobil yang hanya akan dikuasai dengan baik melalui banyak berlatih, tidak hanya menghapal teori.

\section{Manfaat Media Daring sebagai Sarana Belajar Bahasa}

Dari sejumlah bentuk pemanfaatan yang dapat dilakukan atas media daring sebagaimana telah dipaparkan, Proses pembelajaran berlangsung alamiah dalam bentuk kegiatan siswa bekerja dan mengalami, bukan transfer pengetahuan dari guru ke siswa. Strategi pembelajaran lebih dipentingkan daripada hasil. (Depdiknas, 2003) terdapat manfaat yang kemudian dapat diperoleh dari pemanfaatan tersebut. Belajar merupakan suatu proses penting yang berkaitan dengan perubahan perilaku seseorang sebagai akibat dari pengalaman (Black \& Schwartz, 2015; White, 2011). Belajar memegang peranan dalam perkembangan, kebiasaan, sikap, keyakinan, tujuan, kepribadian, dan persepsi seseorang (Rifa'i \& Anni, 2012).Proses pembelajaran yang baik 
akan meningkatkan mutu pendidikan. Mutu pendidikan memiliki pengaruh terhadap perkembangan dan kemajuan suatu negara (Masino \& Niño - Zarazúa, 2016; Skinner, Blum, \& Bourn, 2013).

a. Kemudahan sebagai sarana belajar

Salah satu manfaat dari pemanfaatan media daring sebagai sarana belajar adalah bahwa proses belajar yang terjadi menjadi lebih mudah. Orang tidak lagi harus memegang buku atau catatan. Semuanya telah terfasilitasi dengan adanya ponsel. Cukup melalui ponsel tersebut, masyarakat secara luas serta pembelajar bahasa secara khusus, seperti mahasiswa, dapat mengakses informasi kebahasaan dengan mudah. Informasi tersebut tidak terbatas pada informasi umum seperti definisi kata serta kaidah ejaan yang diperlukan, tetapi juga secara luas dapat berupa permainan intelektual yang menyenangkan untuk diikuti, seperti berupa kuis.

Selain itu, kemudahan tersebut tidak hanya dilihat dari sisi dekatnya masyarakat dengan media daring sehingga proses belajar menjadi lebih efisien, tetapi juga dari segi mudah terjangkaunya oleh masyarakat umum. Dengan kata lain, ilmu bahasa yang umumnya hanya dinikmati pegiat bahasa, akan memiliki kemungkinan juga merambah ke masyarakat secara luas yang pada awalnya memang bukan pegiat apalagi peminat ilmu bahasa. Karena luasnya jangkauan itulah semakin lama kemudian bahasa yang awalnya hanya digemari oleh kalangan terbatas, menjadi sesuatu yang dipelajari secara lebih luas. Dengan demikian, pengetahuan mengenai bahasa tidak hanya dikuasai oleh mereka yang berada dalam bidangnya, tetapi juga seluruh masyarakat Indonesia sebagai pemilik dan penutur asli bahasa tersebut.

b. Menarik minat belajar bahasa

Kemudahan lain yang kemudian diperoleh, berdasarkan manfaat pertama, adalah berupa ketertarikan masyarakat untuk belajar bahasa. Karena media belajar yang ditawarkan mudah diakses, kemungkinan adanya ketertarikan untuk mengetahui lebih lanjut menjadi besar. Apalagi jika kemudian kiriman dalam media sosial, misalnya, ditampilkan dengan cara yang menarik. Salah satunya melalui kuis yang telah dipaparkan sebelumnya.

Cara ini cukup dapat menarik minat penggunaan media sosial, dalam hal ini, instagram untuk minimal menebak jawaban dari kuis. Dari hasil tebakan dalam kuis itulah kemudian responden secara tidak langsung tahu bentuk bahasa yang sesuai dengan kaidah. Dalam hal ini, responden sebagai pemakai media sosial instagram secara tidak langsung belajar dan proses itu dijalaninya tanpa paksaan. Dapat dikatakan bahwa responden belajar sembari bermain, bahkan kemudian muncul keinginan untuk kembali belajar dan terhindar dari rasa bosan. Dengan demikian, ilmu yang kemudian diperoleh menjadi lebih mudah diserap dan diingat.

c. Mengurangi kebosanan belajar

Disebutkan sebelumnya bahwa pembelajaran dengan media daring ini dapat menghindarkan pembelajarnya dari kebosanan. Secara umum, kata belajar sangat erat kaitannya dengan kondisi yang membosankan, tidak nyaman, buku yang bertumpuk, dan waktu yang lama. Namun, dengan adanya aplikasi belajar yang 
praktis dan efisien serta efektif, proses belajar itu akan dilalui dengan lebih menyenangkan, rilesk, dan tentunya tidak lagi membosankan. Pembelajar akan dapat membukanya kapan pun dan di manapun. Ditambah lagi bahwa media belajarnya cukup dengan satu sarana, yaitu ponsel atau gawai sehingga mudah dibuka dan ditutup, tidak juga sulit dibawa dalam segala kondisi. Dengan demikian, keilmuan bahasa, seperti ejaan, yang dianggap rumit dan tidak menyenangkan akan lebih dinikmati dengan lebih terbuka. Penyebab rendahnya hasil belajar yaitu pemilihan metode dan media pembelajaran yang digunakan oleh guru pada proses pembelajaran sangat kurang tepat dan pengelolaan kegiatan pembelajaran yang masih belum dapat membangkitkan motivasi belajar siswa secara optimal (Gumrowi, 2016). Media sendiri adalah sebagai alat komunikasi guna lebih mengefektifkan proses belajar mengajar (Mahbub, Kirana, \& Tadris: Jurnal Keguruan dan Ilmu Tarbiyah Vol.2/2/2017

(Poedjiastoeti, 2016; Woodrich \& Fan, 2017)Manfaat dari penggunaan media ini diharapkan mampu menarik perhatian siswa dan memudahkan siswa dalam memahami materi (Eko Purwanto, Hendri, \& Susanti, 2016). Internet dapat memberikan pengayaan dan komunikasi antara mahasiswa dengan dosen, sesama mahasiswa, atau mahasiswa dengan narasumber lain (Asyhari \& Diani, 2017).

d. Memunculkan kesadaran mengenai bahasa yang benar

Melalui media daring yang mudah, menarik, dan tidak membosankan itu kemudian paling tidak pemikiran masyarakat akan lebih terbuka. Keterbukaan ini tidak hanya berkaitan dengan keinginan untuk belajar bahasa yang sesuai kaidah, tetapi juga dari segi keterbukaan terhadap bentuk bahasa yang benar. Banyak dari masyarakat, bahkan masyarakat berpendidikan yang masih memegang teguh bentuk bahasa yang sedari kecil diperoleh atau yang sudah lazim digunakan dalam kehidupan sehari-hari. Kenyataan bahwa tidak semua bentuk bahasa yang sudah lazim digunakan itu sudah benar sering kali diabaikan sehingga bentuk-bentuk bahasa yang seharusnya justru digunakan, justru tersingkir karena bahkan tidak dikenali oleh penuturnya sendiri. Dengan adanya media belajar daring ini, pengetahuan akan lebih mudah diperoleh sehingga bentuk bahasa yang kemudian dipahami dan diaplikasikan adalah bentuk bahasa yang benar. Lebih jauh, lambat laun bentuk bahasa yang secara meluas banyak yang mengandung kesalahan dapat diminimalisasi dan digantikan dengan bentuk bahasa yang baku.

\section{KESIMPULAN}

Media daring sebagai hal yang sangat dekat dengan masyarakat dapat memberikan dampak positif dan dampak negatif. Kedua dampak tersebut bergantung pada setiap pemakainya sebagai penentu. Dari sisi positif, media tersebut dapat dimanfaatkan untuk belajar, salah satunya belajar bahasa. Bahasa sebagai satu bagian budaya yang penting memiliki porsi yang cukup besar sebagai hal yang harus dikuasai, tidak hanya secara teoretis, tetapi juga secara praktis. Maka, melalui media daring yang sangat dekat masyarakat itu kemudian materi bahasa disampaikan, tidak hanya sebagai penyampai informasi, tetapi juga sebagai sarana praktis. Hal ini diharapkan tidak hanya sebagai kemajuan teknologi semata, tetapi juga benar-benar sebagai jalan praktis untuk 
mencapai keterampilan bahasa yang lebih baik bagi penutur asli bahasa Indonesia. Kondisi ini tidak luput dari 'ancaman' masuknya bahasa asing yang terus memberikan pengaruh pada perubahan bahasa sampai dengan keprestisan bahasa itu bagi setiap individu penutur bahasa Indonesia. Akan lebih baik jika pengetahuan akan bahasabahasa asing yang mempengaruhi tersebut didahului dengan keterampilan bahasa Indonesia yang mumpuni yang dapat digunakan sebagai identitas seorang penutur asli bahasa untuk terus dipertahankan kepemilikannya.

\section{UCAPAN TERIMA KASIH}

Penulis mengucapkan terima kasih kepada dosen pembimbing Bapak Imam Hidayat, M. Pd. atas bimbingan yang diberikan dalam menyelesaikan artikel jurnal ini. Terima kasih juga penulis ucapkan kepada rekan-rekan PBSI yang memberikan motivasi kepada penulis. Semoga artikel jurnal ini dapat menambah wawasan, pengetahuan dan bermanfaat bagi seluruh pihak tentang unsur-unsur yang menyebabkan berkembangnya mistisisme masyarakat Jawa yang masih tetap dipercaya bahkan sampai pada peralihan zaman modern.

\section{DAFTAR PUSTAKA}

Ade1, Filza Yulina. (2017). Pengembangan Media Pembelajaran Berbasis Virtual Class Berbantuan Google Drive Sohibun1. Jurnal Keguruan dan Ilmu Tarbiyah, 2 (2), 121-122.

Atmodjo, Juwono Tri. (2015). Media Massa Dan Ruang Publik. Jurnal Visi Komunikasi, 14 (2), 223-238.

Dunar, Hibram. (2015). My Public Speaking. Jakarta: PT Gramedia Pustaka Utama.

Fransisca, Mona. (2017). Pengujian Validitas, Praktikalitas, Dan Efektivitas Media ELearning Di Sekolah Menengah Kejuruan. Jurnal Pendidikan Teknik Elektro, 2 (1), 17- 22.

https://twitter.com/ivanlanin diunduh pada 31 Juli 2019

https://www.youtube.com/results?search_query=belajar+bahasa+Indonesia diunduh pada 30 Juli 2019

Jabeen, Shazi Shah dan Ajay Jesse Thomas. 2015. "Effectiveness of Online Language." Proccedings of the World Congress on Engineering and Computer Science. Volume 1 WCECS 2015, October 21-23, 2015, USA.

Juwita, Rina. (2017). Media Sosial Dan Perkembangan Komunikasi Korporat. Jurnal Penelitian Komunikasi, 20 (1). 48

Lestari, Ambar Sri. (2013). Pengembangan E-Learning Berbasis Learning Management System Pada Mata Kuliah Media Pembelajaran. Al-Izzah, 8 (2). 
Manggong, L. (2019). The Use of Memes and Whatsapp Message in Teaching Literature. Aksis: Jurnal Pendidikan Bahasa dan Sastra Indonesia 3(1). 12-22. doi: doi.org/10.21009/AKSIS.030102.

Mumin, Abdullah. (2019). the Role Of Information Technology In Education World (Peran Teknologi Informasi Dalam Bidang Pendidikan; E-Education), AlAfkar, Journal For Islamic Studies, 2 (1).

P, Lesari, Wardani, S.,dan Khusniati, M. (2019). Model problem based learning berbantuan jurnal belajar terhadap kemampuan metakognitif siswa. JIPVA (Jurnal Pendidikan IPA Veteran), 3(1), 37-50.

Rahmawati, Devie dan Wiratri Anindhita. (2016). "Potensi Media Daring Menciptakan Komunitas Informasi Transnasional Asean." Prosiding Seminar Nasional INDOCOMPAC. Halaman 730-736.

Rizky, Alin Budiani. (2013). Penggunaan Media Pembelajaran Website E-Learning Berbasis Dokumen Untuk Meningkatkan Hasil Belajar Siswa Pada Pokok Bahasan Mengindeks Dokumen. Universitas Negeri Semarang. Economic Education Analysis Journal, 2 (1).

Unesco. (2003). Internet Education: Support Materials for Education. Moscow: Unesco Institute.

Unicef. (2018). Learning through Play: Stengthening Learning through Play in Early Childhood Education Programmes. USA: Unicef.

Suryani, Yulinda Erma, dan Dwi Bambang Putut Setiyadi. (2017). Kesulitan Belajar Siswa dalam Pembelajaran Bahasa Indonesia Basuki, Fkip Dan Fpsi Universitas Widya Dharma Klaten Litera,16 (1)

Sohibun, Filza Yulina Ade. (2017). Pengembangan Media Pembelajaran Berbasis Virtual Class Berbantuan Google Drive. Tadris: Jurnal Keguruan dan Ilmu Tarbiyah, 2 (2). 121-122 